Чухліб Ю. О., аспірант *

Полтавська державна аграрна академія

\title{
СТАН РОЗВИТКУ ОРГАНІЧНОГО ВИРОБНИЦТВА В УКРАЇНІ Й ПОЛТАВСЬКІЙ ОБЛАСТІ ТА ПЕРСПЕКТИВИ ЙОГО ДОСЛІДЖЕННЯ
}

\section{Рецензент - доктор сільськогосподарських наук, професор В. М. Писаренко}

Обтрунтована потреба в екологізації сільськогосподарського виробництва для сприяння збереження навколишнього середовищча та виробництва безпечної харчової продукиї й сировини. Наведено визначення поняття «органічне сільське господарство» та зазначені його основні особливості. Проведено огляд літературних джерел щзодо стану й тенденцій розвитку органічного сільськогосподарського виробництва в Украӥні, зокрема в Полтавській області. Окреслено основну проблематику дослідження щзодо сфери органічного виробництва в найближчі роки.

Ключові слова: екологізачія, органічне виробниитвво, альтернативне землеробство, біологізація, сертифікаиія, стандарти, перехідний період.

Постановка проблеми. Внаслідок інтенсифікації землеробства в другій половині XX ст. агросфера України зазнала неабиякого антропогенного тиску, наслідком якого стало порушення екологічної рівноваги в навколишньому середовищі та всебічні деградаційні процеси в системі ведення сільськогосподарського виробництва, зокрема, землеробстві. Ці процеси, що тривають і дотепер, включають у себе втрату родючості грунтів, посилення водної та вітрової ерозій, погіршення агрофізичних властивостей грунту, порушення його водного, повітряного й теплового балансів, забруднення внаслідок нераціонального і необгрунтованого внесення мінеральних добрив та пестицидів.

Внаслідок того, що існуюча система ведення сільськогосподарського виробництва не відповідає сучасним вимогам раціонального, сталого землекористування, що, в свою чергу, негативно позначається на якості харчової продукції й сировини, джерелом якої $є$ сільське господарство. У зв'язку з цим виникла об'єктивна необхідність в екологізації сільськогосподарського виробництва, запровадженні альтернативних до традиційних методів господарювання. Однією 3 таких альтернативних систем господарювання $\epsilon$ органічне виробництво. Воно, зокрема, сприяє зба- лансованому природокористуванню, збереженню та покращанню родючості грунтів, біологізації землеробства (використання органічних добрив), підтриманню й підвищенню рівня біорізноманіття в агросфері та біологічній активності грунту, використанню відновлювальних ресурсів, утилізації побічних відходів виробництва.

Аналіз останніх досліджень i публікацій, у яких започатковано розв'язання проблеми. Серед вітчизняних вчених дослідженням передумов розвитку органічного виробництва, його запровадження та функціонування займалися такі вчені, як М. К. Шикула, Н. М. Рідей, М. В. Капштик $[8,9]$. Їх праці присвячені питанням грунтозахисного обробітку грунту, його впливу на родючість грунту, а також грунтозахисним технологіям - передумові органічного виробництва. Шерстобоєва О. В. [15] досліджувала передумови для розвитку органічного виробництва в Україні, Н. А. Макаренко - екологічну експертизу технологій вирощування сільськогосподарської продукції, Ю. П. Манько - питання ефективності екологічного землеробства, С. С. Антонець, В. М. Писаренко, П. В. Писаренко [1, 12, 14] - питання біологізації землеробства, в тому числі, ii регіональний аспект (Полтавська область). Крім того, О. І. Корніцька [11] розглядала екологічні та соціально-економічні, а О. Т. Дудар - організаційно-економічні аспекти органічного виробництва. А. С. Антонець, В. В. Писаренко [2], В. І. Артиш [3], Т. О. Зайчук [7] займалися питанням розвитку та становлення ринку органічної продукції, Є. В. Милованов - особливостями органічного руху в Україні, П. М. Скрипчук, Г. М. Шевчук - еколого-економічними аспектами розвитку органічного виробництва, Н. А. Берлач висвітлювала правові аспекти процесу органічного виробництва.

Мета досліджень: аналіз розвитку та дослідженості процесу органічного виробництва в Україні, зокрема на Полтавщині, на основі наукових даних літературних джерел.

* Керівник-доктор сільськогосподарських наук, професор П. В. Писаренко 
Завдання досліджень. Систематизація основних літературних даних щодо становлення та розвитку органічного виробництва в Україні й Полтавській області; обгрунтування на основі зроблених висновків майбутнього напряму дослідження в рамках наукової роботи.

Матеріали і методика досліджень. Матеріалами дослідження стали літературні джерела (наукові праці, монографії, статті, автореферати) вітчизняних вчених. У дослідженні використовувалися теоретичні методи аналізу (співставлення, порівняння, систематизація, класифікація) та метод синтезу.

Результати досліджень (огляд літератури).

Термінологічні аспекти визначення поняття «органічне сільське господарство»

Особливістю органічного виробництва на сьогодні $є$ те, що немає його універсального, єдиного термінологічного визначення як на міжнародному рівні, так і в Україні. Наведемо для прикладу основні його визначення:

По-перше, варто зазначити, що міжнародно визнаними англомовними синонімами органічного («organic») сільського господарства $\epsilon$ терміни «біологічне» («biological») та екологічне («ecological»). Відповідно, від цих визначень формуються терміни різними мовами країн, в яких застосовуються прийоми органічного виробництва [16]. В Україні використовується термін «органічне» сільське господарство згідно з першим українським приватним сертифікаційним органом «Органік стандарт». Він здійснює сертифікацію органічної продукції відповідно до стандартів $€ С$ та є офіційно визнаним Європейською комісією, контролюючим органом щодо органічного виробництва в Україні (реєстраційний номер - UA-BIO-108), що дозволяє експортувати сертифіковану ним продукцію в країни Європейського союзу без отримання імпортного дозволу [13]. Крім того, широковживаним терміном у вітчизняній науці для позначення органічної системи землеробства $є$ термін «альтернативне» землеробство.

За IFOAM (Міжнародною федерацією руху за органічне сільське господарство), органічне сільське господарство - ие виробнича система, що підтримує здоров'я трунтів, екосистем і людей. Вона спирається на екологічні прочеси, біорізноманіття $i$ ичикли, адаптовані до місцевих умов, замість використання зовнішніх (вхідних) ресурсів із негативними побічними ефектами. Органічне сільське господарство поєднує в собі традииії, інноваиії та науку в інтересах навколишнього середовища, сприяючи ичим самим, справедливим відносинам $i$ хорошій якості життя для всіх зацікавлених сторін [16].

$\mathrm{y}$ цілому - це цілісний системний підхід, заснований на багатьох процесах, що сприяють сталості екосистеми, безпечності харчових продуктів, добробуту тварин і соціальній справедливості [16].

Згідно з європейським стандартом щодо органічного виробництва, Постановою Ради (СС) № 834/2007 від 28 червня 2007 року, органічне виробниитво - ие иілісна система господарювання та виробництва харчових продуктів, яка поєднує в собі найкращі практики з огляду на збереження довкілля, рівень біологічного різноманіття, збереження природних ресурсів, застосування високих стандартів належного утримання (добробуту) тварин та метод виробництва, який відповідає певним вимогам до продуктів, виготовлених із використанням речовин та прочесів природного походження [6].

Відповідно до стандарту «Кодекс Аліментаріус. Органічні харчові продукти», який був запроваджений Комісієї «Кодекс Аліментаріус» (спільна програма підрозділів ООН - ФАО і ВОО3 по стандартах на харчові продукти), органічне сільське господарство - ие єдина система управління виробництвом, що дає можливість підтримувати і покращувати санітарний стан агроекосистеми, в тому числі біорізноманіття, біологічний кругообіг $i$ біологічну активність трунту [10].

Науково-теоретичні та практичні засади органічного виробництва в Украйні й Полтавській області

Науково-методичні і теоретичні основи для екологізації сільськогосподарського виробництва в Україні були закладені ще наприкінці XIX століття. Це ідеї пов'язані передусім із обробітком грунту без обертання скиби (I. С. Овсінський, 1899), що знайшли своє продовження в другій половині XX ст. у працях вчених, пов'язаних iз безплужним (переважно плоскорізним) обробітком грунту (Т. С. Мальцев, 1954; А. І. Бараєв, 1965; А. Н. Каштанов, 1974; С. С. Рябов, 1975 та ін.). Дані ідеї спочатку лягли в основу методу боротьби з вітровою і водною ерозіями в Казахстані, Сибіру та Заураллі. Власне, саме ці два головних несприятливих фактори й стали головною причиною пошуку способів удосконалення та екологізації системи традиційного екстенсивного землеробства. Вітчизняними вченими було вирішено чимало теоретичних і практичних питань стосовно ефективного ведення грунтозахисного землеробства на територіях, що знаходять- 
ся під впливом водної і вітрової ерозій у Лісостепу і Степу України (С. С. Соболєв, 1948; М. Н. Заславський; 1965, М. К. Шикула, 1968; О. Г. Тараріко, 1984).

У 1973 році розпочався Полтавський великомасштабний експеримент (1973-1988 рр.), великомасштабний тому, що в ньому були задіяні всі господарства Полтавської області. Суть даного експеременту полягала в адаптації грунтозахисної системи землеробства до умов України на території Полтавській області. В 1976 році під керівництвом Ф. Т. Моргуна, відомого українського наукового i громадського діяча, доктора сільськогосподарських наук, академіка Національної академії аграрних наук України, першого секретаря Полтавського обкому компартії України (1972-1988 рр.), М. К. Шикули доктора сільськогосподарських наук, професора, заслуженого діяча науки і техніки України, та за участі С. С. Антонця - засновника й президента ПП «Агроекологія» Шишацького району Полтавської області, Героя Соціалістичної Праці, Героя України, тодішнього голови колгоспу імені Орджонікідзе Шишацького району (с. Михайлики, з 1992 по 2000 р. - САТ «Обрій», з 2000 р. - ПП «Агроекологія») розпочалася розробка та провадження даної грунтозахисної системи землеробства [5].

На всій території господарства 31976 року застосовується грунтозахисний, без обертання скиби, різноглибинний обробіток грунту; з 1979 року тут відмовилися від застосування агрохімікатів на полях (ними оброблялося тільки посівне насіння). 31986 року перейшли на методи біологізації землеробства (використання нетоварної частини врожаю, сидератів), із 1990 року застосовується мінімальний грунтозахисний обробіток грунту (на 10-12 см під усі культури сівозмін), із 1996 р. відмовилися від застосування мінеральних добрив; iз 1997 р. застосовується мінімальний (4-5 см) обробіток грунту. Це дало змогу виробляти екологічно безпечні продукти харчування та сировину, в тому числі для потреб харчової промисловості, що спеціалізується на виробництві продуктів для дитячого харчування $[1,2,12]$.

До розробки та впровадження грунтозахисної системи землеробства в умовах України доклали зусиль і такі вчені як О. Г. Тараріко, Н. М. Рідей, М. В. Капштик, М. М. Доля та інші [12].

Понад тридцятирічним практичним досвідом ПП «Агроекологія» доведено, що грунтозахисний безплужний обробіток грунту разом з органічними добривами $\epsilon$ ефективним прийомом відновлення родючості грунтів, які зазнали агрофізичної деградації внаслідок інтенсифікації сільськогосподарського виробництва. Крім того він є основою органічного землеробства.

Технологічні прийоми органічного виробництва, що застосовуються в ПП «Агроекологія», спрямовані на раціональне використання земельних ресурсів, протидію ерозійним процесам та агрофізичній деградації грунтів, підвищення їх родючості шляхом відтворення природних біологічних процесів, а також на безпечну боротьбу з бур'янами, шкідниками, хворобами. Крім того передбачається повна або часткова відмова від використання синтетичних речовин: розчинних мінеральних добрив, пестицидів, регуляторів росту та ГМО (генетично модифікованих організмів та їх похідних). Методи органічного виробництва передбачають застосування комплексу агротехнічних заходів, що грунтуються на суворому дотриманні сівозмін, уведенні до їх складу бобових культур, проведення поверхневого обробітку без обертання скиби, мульчування верхнього шару грунту поживними рештками, широке застосування органічних добрив (гною, компостів, сидератів), захисту рослин агротехнічними і біологічними методами [2, 14].

Так, одними 3 найважливіших умов для переходу до господарювання на принципах органічного виробництва є необхідне системне застосування грунтозахисних технологій із мінімальним безполицевим обробітком грунту, внесення достатньої кількості органічних добрив (нетоварної частини врожаю, гною, сидератів) та екологічно збалансовані сівозміни. [8, 9]. Однією 3 необхідних і важливих умов біологізації сільськогосподарського виробництва $є$ активізація діяльності грунтової мікрофлори. Таке управління процесами грунтової родючості полягає в перебудові мікробного ценозу фітосфери шляхом збагачення грунту органічними речовинами, а ризосфери рослин - активними штамами мікроорганізмів-антагоністів фітопатогенів, азотфіксуючих і фосформобілізуючих мікроорганізмів, які селекціоновані з високопродуктивних природних фітоценозів і агрофітоценозів [15].

\section{Сертифікація $і$ стандарти органічного} виробництва

Сільськогосподарське виробництво для підтвердження статусу виробника органічної продукції повинне пройти процедуру сертифікації, тобто перевірки відповідності вимогам (стандартам) органічного виробництва.

Варто зауважити, що особливістю процесу органічного виробництва є те, що воно грунтується 
на системному контролі, тобто на оцінці методів виготовлення продукції, а не лише на оцінці вихідного продукту. Головна ідея органічного виробництва - це господарська діяльність у гармонійно збалансованій взаємодії з природою і якомога меншою залежністю від зовнішніх вхідних ресурсів (палива, синтетичних добрив, засобів захисту рослин та ін.). Ідеальною моделлю органічного виробництва $є$ змішане, системно замкнене (безвідходне) органічне господарство 3 одночасним отриманням продукції рослинництва і тваринництва, за оптимального і необхідного для потреб обох сфер виробництва, науково обгрунтованого поєднання оброблювальних земель (ріллі), полів із багаторічними травами, а також кормовими культурами [4].

Сертифікацію здійснюють відповідно до стандартів органічного виробництва. На сьогодні виділяють три головні групи стандартів:

Міжнародні приватні або міжурядові рамочні стандарти:

- Базові стандарти IFOAM (IFOAM Basic Standards - IBS).

- Спільна програма ФАО (FAO) i BOОЗ (WHO) по стандартах на харчові продукти - Комісія «Кодекс Аліментаріус» - «Кодекс Аліментаріус. Органічні харчові продукти».

Основоположні стандарти або Директиви:

- Постанови Ради Європейсього Союзу або Регламенти Комісії Свропейського Союзу. Постанова Ради (СС) № 834/2007 від 28 червня 2007 року стосовно органічного виробництва та маркування органічних продуктів і скасування Постанови (СЕС) № 2092/91; Регламент Комісії (ЄС) №889/2008 від 5 вересня 2008 року, що встановлює детальні правила щодо органічного виробництва, маркування і контролю для впровадження Постанови Ради (СС) №834/2007 стосовно органічного виробництва i маркування органічних продуктів; Регламент Комісії (СС) № 967/2008 від 29 вересня 2008, Регламент Комісії (ЄС) № 1235/2008 від 8 грудня 2008 року, Регламент Комісії (СС) № 1254/2008 від 15 грудня 2008, Регламент Комісії (СС) № 537/2009 від 19 червня 2009, Регламент Комісії (СС) № 710/2009 від 5 серпня 2009 року, Регламент Комісії (СС) № 271/2010 від 24 березня 2010 року.

- Американська національна органічна програма - NOP (National Organic Program) Miнicтерства сільського господарства США (United States Department of Agriculture - USDA).

- JAS (Japanese Agricultural Standard) - Японський стандарт якості сільськогосподарської продукції, до складу якого входить «особливий стандарт» щодо виробництва і переробки органічної продукції.

- Швейцарія, Ізраїль, Аргентина, Австралія мають органічні стандарти, рівнозначні Постанові Ради (ЕС) № 834/2007.

Приватні Стандарти органічного виробництва:

- Demeter, Naturland, Bioland, Ecoland, Biokreis, Ecovin (Німеччина); Soil Association (Великобританія); Bio Suisse (Швейцарія), Bio Austria, Austria Bio Garantie (Австрія), KRAV (Швеція), БІОЛан (Україна) та інші.

Щодо України, то тут процес законотворення стосовно органічного виробництва триває з 2007 року, коли на розгляд Верховної Ради України був внесений перший проект закону України «Про органічне виробництво». Станом на 8 лютого 2012 року в Україні відсутнє офіційно прийняте законодавство щодо органічного виробництва, існує лише прийнятий за основу до розгляду комітетом Верховної Ради України з питань екологічної політики, природокористування та ліквідації наслідків Чорнобильської катастрофи проект закону України «Про засади органічного виробництва» № 9707-1 від 18.01.2012 року.

За відсутності вітчизняної законодавчої й нормативно-правої бази стосовно органічного виробництва, що, до речі, вважається одним із головних стримуючих чинників розвитку ринку органічної продукції в Україні [7, 11], сертифікація органічних виробників і їх продукції здійснюється згідно 3 міжнародними стандартами. Зокрема, українська сертифікаційна компанія «Органік стандарт» сертифікує органічних виробників відповідно до «Стандарту 3 органічного виробництва та переробки для третіх країн, рівнозначному стандарту Свропейського Союзу» (Постанові Ради (СС) № 834/2007 та Регламенту Комісії (СС) № 889/2008).

Врегулювання ринку органічних продуктів в Україні є необхідною і важливою умовою реалізації державної політики в сфері безпеки харчової продукції та сировини. Крім зазначених проблем у сфері органічного виробництва виділяють також ті, що потребують нагального вирішення, a саме: відсутність державної підтримки та сприяння органічним виробникам (субсидування, пільгове кредитування, дотаціі); обмеженість асортименту продукції; не налагодженість постійних каналів збуту; відсутність належного маркетингового досвіду щодо реалізації такої продукції; недостатня обізнаність споживачів відносно особливостей органічної продукції та цінова політика щодо органічного виробництва, що потребує наразі свого удосконалення (ціни 
на органічні продукти під час вищі за звичайні) $[3,7]$.

Висновки. Органічне виробництво залишається важливою галуззю розвитку АПК України і необхідною умовою екологізації сільськогосподарського виробництва. Не виникає сумніву, що для його розвитку потрібна не лише комплексна державна підтримка, але й ефективна науково-методологічна база. Незважаючи на те, що на сьогодні у вітчизняній науці існують до-

\section{БІБЛІОГРАФІЯ}

1. Антонеиь С. С. Регіональний аспект біологізації землеробства: напрямки досліджень, здобутки і перспективи / С. С. Антонець, В. М. Писаренко, М. М. Опара // Вісник Полтавського державного сільськогосподарського інституту. 2001. - № 4. - C. 15-19.

2. Антонеиь A. C. Формування ринку екологічно безпечної продукції при органічному землеробстві / А. С. Антонець, В. В. Писаренко, Т. В. Лук'яненко [та ін.] // Економіка АПК. 2010. - № 12. - C. 75-79.

3. Артиш В. I. Організаційно-економічні передумови формування ринку екологічно чистої продукції / В. І. Артиш // Економіка АПК. 2009. - № 2. - C. 117-120.

4. Борживой Шарапатака. Органическое сельское хозяйство / Борживой Шарапатака, Иржи Урбан. - Чешская Республика : Биоинститут, Оломоуц, 2010. - 398 с.

5. Відтворення родючості грунтів у грунтозахисному землеробстві / Шикула М. К., Антонець С. С., Андрієнко В. О. [та ін.]; під ред. М. К. Шикули. К. : Оранта, 1998. — 680 с.

6. Довідник стандартів ЄС щодо регулювання органічного виробництва та маркування органічних продуктів. - Кн. 1. / За ред. С. Милованова, С. Мельника, О. Демидова [та ін.]. - Л. : ЛА «Піраміда», Федерація органічного руху України, 2008. - $204 \mathrm{c}$.

7. Зайчук T. О. Виробництво екологічно чистих продуктів харчування як стратегічний напрямок розвитку України / Т. О. Зайчук // Економіка і регіон : науковий вісник - Полтава : ПолтНТУ. - 2009. - № 1 (20). - С. 59-66. слідження щодо органічного виробництва та різноманітних його аспектів, поглибленого опрацювання потребують ще чимало питань. Передусім це стосується технологічних аспектів виробництва, особливо в розрізі формування методів переходу до органічних форм господарювання й технологій вирощування продукції рослинництва і тваринництва для відповідності нормам органічних стандартів, а також пошук шляхів та ефективних моделей органічного виробництва.

8. Капштик М. В. Відтворення органічної речовини чорноземів як передумова органічного виробництва / М. В. Капштик // Вісник аграрної науки. - 2009. - № 9. - С. 8-13.

9. Капштик М. В. Грунтозахисні технології як передумова органічного землеробства / М. В. Капштик, О. В. Демиденко // Агроекологічний журнал. - 2011. - № 2 . - С. 52-58.

10. Кодекс Алиментариус. Органические пищевые продукты / Пер. с англ.; ФАО, ВОЗ. - М. : Весь Мир, 2006. - 72 с.

11. Корніцька О. I. Перспективи розвитку ринку органічної продукції в Україні / О. І. Корніцька // Вісник Полтавської державної аграрної академії. - 2008. - № 3. - С. 131-136.

12. Органічне землеробство: 3 досвіду ПП «Агроекологія» Шишацького району Полтавської області. Практичні рекомендації / Антонець С. С., Антонець А. С., Писаренко В. М. [та ін.]. - Полтава: РВВ ПДАА, 2010. -200 с.

13. Офіційний сайт сертифікаційного органу «Органік стандарт» [Електронний ресурс] - режим доступу: http://www.organicstandard.com.ua

14. Писаренко В. М. Основні напрями інтегрованого захисту рослин в умовах органічного землеробства / В. М. Писаренко // Вісник Полтавської державної аграрної академії. - 2008. - № 4. - C. 14-18.

15. Шерстобосва О. В. Екологічні, економічні та соціальні передумови біологічного землеробства / О. В. Шерстобоєва // Агроеколгічний журнал. - 2007. - № 1. - С. 67-70.

16. The IFOAM standart for organic production and processing. Draft Version 0.2. - 2011. 